\title{
Mandatory International Financial Reporting Standards 7 (IFRS 7) Disclosure by Listed Banks in Nigeria
}

\author{
Adamu Garba Zango*
}

Hasnah Kamardin

Rokiah Ishak

School of Accountancy, College of Business, Universiti Utara Malaysia, Malaysia

Email: zangoage@yahoo.com, hasnahk@uum.edu.my, rokiah@uum.edu.my

\section{Doi:10.5901/ajis.2015.v4n2p435}

\begin{abstract}
The paper assesses the extent of mandatory compliance with international financial reporting standards 7 (IFRS7) by fourteen listed banks on the Nigerian stock exchange. Using a disclosure checklist of 132 mandatory disclosure requirements, the study covers a two year period of 2012 and 2013. Findings from the study reveal non-compliance with disclosure requirements. However, compliance is above average for the two years under study, an improvement is nonetheless recorded if the two years of the study are compared. Based on the result, it is recommended that monitoring and enforcement mechanisms of the Financial Reporting Council (FRC) especially on bank surveillance should be given urgent priority in view of the complex nature of banking and the need to mitigate banking crisis in Nigeria. Although Nigeria is only two years into the adoption process, banks in Nigeria can do better than what is reported in the current study.
\end{abstract}

Keywords: IFRS 7, mandatory compliance, banks, Nigeria.

\section{Introduction}

The extent of compliance with disclosure requirements determines the usefulness of financial reporting figures in the eyes of investors in annual reports. Prior to the effort of international accounting standards board (IASB) in 2002, uniform accounting and reporting standards on universal basis remain a mirage because each country is a designer of their own financial reporting framework. The lack of transparent and comparable information in financial statements creates a wide gap in the search for international trade and investments. Investors were handicap for trading across borders due to unfamiliar accounting and reporting language even if the reports are beautifully packaged. Inadequate disclosure in financial report is capable of preventing international portfolio diversification among investing communities hence optimum investments (Amoako \& Asante, 2012). This means that jurisdiction specific standards can result in lack of or inadequate international finance through stock trading (IASC, 1996).

The IASB as the architect of principles based accounting unison, kick started the move towards a globalised accounting harmonisation defined as narrowing down differences in accounting practice between countries beginning with the European commission in 2005. The harmonisation has as its ultimate aim the provision of a single set of universal accounting language that is acceptable by all jurisdictions. This was kick started through the issuance of comprehensive, transparent and comparable international accounting standards known as IFRSs by the IASB in 2002. These standards are intended for use by all without regard to an investor's country of origin or nationality (Choi, Forst \& Meek, 2002). This idea was endorsed by the European commission (EC) in 2002 with the passage of legislation mandating all European Union (EU) listed companies to prepare their consolidated financial statements using international accounting standards (IAS) effective January 1, 2005 (EC, 2005).

Today over 270 countries have either adopted or require IFRS as their financial reporting framework for use in business and commercial activities (IASB, 2005; PwC, 2013). Nigeria is not left behind in the historic revolution in financial reporting (Damant, 2002). The International Financial Reporting Standards (IFRS) were fully adopted in 2010 to take effect from January 1, 2012 with listed entities (Banks, Insurance, Petroleum sub-sector, Telecommunication) as pioneer implementers (Ayuba, 2012; Bala, 2013; Edogbanya \& Kamardin, 2014). Banks being the engine of growth of every nation is among the first compliant companies because of their peculiar position as very high information 
asymmetry sector with high concentration of risks (Andres et al., 2012).

With globalisation comes the need for cross border trade and investments. Banks in Nigeria are now seizing the opportunity to open off shore branches and transact in all forms of financial instruments ranging from depository receipts, derivatives and act as agents through, which foreign direct investments (FDIs) are facilitated. IFRS 7 has as its principal objective the enhancement of stakeholder understanding of financial report of banks with regard to their performance, cash flows and profitability at any point in time (Kirk, 2005). The demand for more information on risks has assumed monumental dimensions with the promulgation and subsequent enhancement of IFRS 7 by the IASB in 2007.

According to the Bank of International Settlement (BIS, 2014) the total global over the counter derivatives outstanding as at December 31, 2013 was $\$ 710.63$ trillion. However, the value fell slightly as at June 30, 2014 to stand at $\$ 691.49$ trillion. This phenomenal growth in derivatives trading resulted in colossal losses especially in the US and Australia where Barings Bank Plc lost over \$1 billion and Australian National Bank losing over \$360 million through options trading in foreign exchange (Denning, 2013; Kemp, 2004; BIS, 2013). These consequential losses led professionals and researchers to wonder whether the financial reporting framework for financial instruments disclosure is indeed adequate both in form and context to allow for proper assessment of risks and uncertainties surrounding this form of trading by investors (Amoako \& Asante, 2012; Tan, 2005). With growth in derivative accounting and the resultant negative effects there from comes the need for an in depth knowledge of the products technicalities so as to enhance shareholder value (Amoako \& Asante, 2012; Tan, 2005). It also calls for higher standards of risk management, strict monitoring of the operators and regulatory enforcement (Wikipedia, 2014).

On the issue of losses due to derivatives trading, the International Accounting Standards Board and other researchers were quoted as lamenting the inability of external auditors to detect non-compliance with standards when it was obvious that most of the company's disclosure status were not absolute (Glaum \& Street, 2003; Street \& Gray, 2001; $I A S B, 2005)$. The issue of disclosure calls for extra vigilance not only by the independent auditors but also the regulatory authorities to strengthen their regulatory apparatus of monitoring to ensure total compliance (Amoako \& Asante, 2012; Glaum \& Street, 2003). The derivative losses also confirm Daske et al. (2007) who classify IFRS compliant companies into serious and label adopters because this is a clear case of non-compliance. This is also a wide gap in knowledge of IFRS 7 disclosure especially in the banking sector in Nigeria, which required to be filled.

Drawing from previous experiences of developed nations, this paper intends to examine compliance with IFRS 7 by listed banks in Nigeria a developing country, which mandatorily adopted the principles base framework since September 28, 2010 and started implementation on January 1, 2012 (Bala, 2013; Edogbanya \& Kamardin, 2014). This is done with a view to finding whether or not financial statements of Nigerian listed banks in the early stage of adoption can be relied upon to provide the needed transparency and comparability in this globalised market (Spector, 2009). This paper is organised in four sections. Section one is the introduction and review of literature relevant to IFRS compliance. Section 2 discusses the methodology; section 3 is the study's findings and analysis, while the last section concludes the paper.

\section{Methods and Data}

The samples of study are listed banks on the first tier floor of the Nigerian Stock Exchange (NSE) as at January 1, 2012. The study covers two years 2012 and 2013. Fourteen banks out of nineteen are selected because they are the ones whose financials are available. Banks are studied because according to Andres and Vallelado (2008) and Andres et al. (2012) they are the engine of growth of every economy. Thus, insight into their wellbeing through constant research should be of interest to all (Amoako \& Asante, 2012). IFRS 7 financial instruments disclosure is chosen for the study because there is ample evidence of problems associated with derivative accounting across the globe hence the need for extra vigilance in Nigeria (Amoako \& Asante, 2012; Chalmers, 2001). The paper uses secondary data for two years 2012 and 2013 from the bank's annual reports and statement of accounts obtained through the World Wide Web and where it is not available from the Nigerian Stock Exchange fact year book (NSE, 2013).

\subsection{The compliance index}

The level of mandatory compliance with IFRS 7 disclosure requirements is measured using a mandatory disclosure index (MDI) which has been shown as a reliable measurement technique in compliance studies (Marston \& Shrives, 1991) and is consistent with prior literatures (Abdullah, 2013; Hossain, 2014; Street \& Gray, 2001; Glaum \& Street, 2003). The checklist is also used by audit firms to check their clients' compliance with IFRS (PWC, 2013). The index gives a summary 
of IFRS 7 disclosure requirements into a composite figure using dummy range from zero to one which determine level of compliance of each bank (Amoako \& Asante, 2012). A relative score, which is the ratio of what a bank disclosed in its annual report to what it is expected to disclose under IFRS 7 in each year of investigation is computed for each bank. The constituents of the disclosure index are mandatory information items, therefore scores obtained by each bank is interpreted as its mandatory items, derived by using the following unweighted scoring formula used in prior studies (Abdullah, 2013; Barako et al. 2006).

$$
C S_{J}=\frac{T \sum_{i=1}^{m} d i}{M=\sum_{i=1}^{n} d i}
$$

Where:

$\mathrm{CS}_{\mathrm{J}}=$ total compliance score for each company in which $0 \leq \mathrm{CSj} \leq 1$

$\mathrm{T}=$ Total number of items disclosed $\left(\mathrm{d}_{\mathrm{i}}\right)$

$\mathrm{J}=$ name of the company under consideration

$M \leq n$; where $m$ is the total number of applicable items the company $j$ is to disclose

\section{Results and Discussion}

This paper employs a disclosure index from PricewaterhouseCoopers (PwC, 2013) to analyse data and determine level of IFRS 7 compliance by all the fourteen sampled banks in Nigeria for two years i.e. 2012 and 2013. The overall compliance of all the fourteen listed banks are reported in table 1 and 2.

\subsection{Descriptive Statistics}

Table 1 below depicts the total IFRS 7 disclosure requirements for the two years i.e. 2012 and 2013 respectively.

Table 1: Disclosure requirements of IFRS 7

\begin{tabular}{|c|c|c|c|}
\hline Year & Disclosure items & Not applicable & Applicable \\
\hline 2012 & 132 & 11 & 121 \\
\hline 2013 & 132 & 11 & 121 \\
\hline
\end{tabular}

From table 1 above, eleven disclosure items labeled not applicable are removed because they fall under the disclosure requirements of hedge transactions, which Nigerian listed banks are not participants and therefore not required to disclose (IMF, 2013; Tijjani \& Ajape, 2013). Appendix 2 shows the disclosure score of each sampled bank.

\subsection{Compliance Scores}

The compliance scores for each of the listed banks in respect of the two years 2012 and 2013 are shown in table 2.

Table 2: IFRS 7 compliance scores

\begin{tabular}{|c|c|c|c|c|c|c|c|c|}
\hline S/N & Bank Name & $\begin{array}{c}\text { Total compliance } \\
\text { index }\end{array}$ & $\begin{array}{c}\text { Not applicable } \\
\text { in 2012 \& 2013 }\end{array}$ & $\begin{array}{c}\text { Applicable in 2012 } \\
\& 2013\end{array}$ & $\begin{array}{c}\text { Compliance } \\
\text { level (2012) }\end{array}$ & $\begin{array}{c}\text { Compliance } \\
\text { Level (2013) }\end{array}$ & $\begin{array}{c}\text { \%Compliance } \\
(2012)\end{array}$ & $\begin{array}{c}\text { Compliance } \\
(2013)\end{array}$ \\
\hline 1 & Access & 132 & 11 & 121 & 80 & 85 & 66.1 & 70.2 \\
\hline 2 & Diamond & 132 & 11 & 121 & 60 & 62 & 49.6 & 51.2 \\
\hline 3 & Eco & 132 & 11 & 121 & 60 & 60 & 49.6 & 49.6 \\
\hline 4 & Fidelity & 132 & 11 & 121 & 60 & 64 & 49.6 & 52.9 \\
\hline 5 & First & 132 & 11 & 121 & 90 & 90 & 74.4 & 74.4 \\
\hline 6 & First City & 132 & 11 & 121 & 60 & 65 & 49.6 & 53.7 \\
\hline 7 & GTBank & 132 & 11 & 121 & 90 & 90 & 74.4 & 74.4 \\
\hline 8 & Skye & 132 & 11 & 121 & 50 & 57 & 41.3 & 47.1 \\
\hline 9 & Stanbic & 132 & 11 & 121 & 80 & 83 & 66.1 & 68.6 \\
\hline 10 & Sterling & 132 & 11 & 121 & 50 & 54 & 41.3 & 44.6 \\
\hline 11 & UBA & 132 & 11 & 121 & 80 & 80 & 66.1 & 66.1 \\
\hline 12 & UBN & 132 & 11 & 121 & 30 & 55 & 24.8 & 45.5 \\
\hline 13 & Unity & 132 & 11 & 121 & 60 & 61 & 49.6 & 50.4 \\
\hline 14 & Zenith & 132 & 11 & 121 & 90 & 89 & 74.4 & 73.6 \\
\hline & Average & & & & 67.14 & 71.07 & 55.5 & 58.7 \\
\hline
\end{tabular}


Table 2 above depicts details of compliance with disclosure requirements of IFRS 7 by listed banks in Nigeria. These scores are also shown in appendix 2.

\subsection{Comparative Analysis}

This paper observes some improvements in IFRS 7 compliance level by most banks in 2013 compared to 2012. This improvement may be as a result of additional IFRS knowledge through training, conferences, seminars and workshops (national \& international) by the board of directors, management and line staff of the banks consistent with findings in previous studies (Amoako \& Asante, 2012). Bader (2005) also reports an improvement in compliance by banks in the Gulf Cooperation Council member states between 1996 and 2002. In this study, the scores for 2012 are 55.5\% while that of 2013 is 55.5\%. Although there is an increase in compliance, the average score for the two years is less than $60 \%$ the result show low compliance. This result support prior compliance study by Street and Bryant (2000) who's finding documents overall compliance for their studied sample to be equal to or less than $75 \%$ but does not support the result of Amoako and Asante (2012) who's finding recorded an average compliance of $94.7 \%$ in 2008 and $98.2 \%$ in 2009 for Ghanaian listed banks.

\subsection{Monitoring and Enforcement}

The results of study challenge the accounting regulators like the Financial Reporting Council (FRC) and the Securities and Exchange Commission (SEC) in Nigeria on the need put their monitoring and enforcement mechanism to proper use. This is because, with an average of 55.6\% and 58.7\% level of compliance in 2012 and 2013 two years into the adoption process, Nigerian listed banks compliance level falls short of expectations when compared with other developing economies (Amoako \& Asante, 2012; Bader, 2005).Furthermore, the independent auditors who incidentally audit thirteen out of the fourteen banks under study must also do everything possible to ensure full compliance. This call is in line with Hodgdon et al. (2009) and Amoako and Asante (2012) who's study confirm compliance level to be positively related to the "Big 4"audit firms due to their knowledge and reputational value, which ensures compliance with disclosure requirements of the standards.

\section{Summary and Conclusion}

This paper assesses mandatory compliance with disclosure requirements of IFRS 7 by listed banks on the main board of Nigerian Stock Exchange for two years 2012 and 2013 using disclosure index containing 132 mandatory items (Mainoma \& Adejola, 2010; PwC, 2013). The compliance score in percentage for the two years is slightly above average with $55.5 \%$ and 58.7\% in 2012 and 2013 respectively. According to the World Bank and International Monetary Fund Joint Inspection Report, although Nigeria is only two years into the adoption process, listed banks in Nigeria can do better than what is reported in the current study (WB/IMF, 2013). These regulators opine that Nigeria has since 2007 adopted the Investment and Securities Act (ISA, 2007), enhance the Nigerian Securities and Exchange Commission Act (SEC, 2011) and have adopted the IFRS since 2012 (IMF/WB, 2013.4). It is therefore recommended that monitoring and enforcement mechanisms by the Financial Reporting Council (FRC) especially on bank surveillance should be given urgent priority in view of the complex nature of banking and the need to mitigate a repeat of the 2004 banking crisis in Nigeria.

\section{References}

Abdullah, M. (2013). Quality of corporate mandatory disclosure in Malaysia: evidence from two methods. 4th international conference on business and economic research (4th ICBER 2013) proceeding, March 2013. Golden flower hotel, Bandung, Indonesia. Website: www.internationalconference.com.my.

Akhtaruddin, M., Hossain, M. L., Hossain, M. \& Yao, L. (2009). Corporate governance and voluntary disclosure in corporate annual reports of Malaysian listed firms. JAMAR, 7 (1), 1-19.

Amoako, G. K \& Asante, S. (2013). Compliance with international financial reporting standard 7 (IFRS 7): a study of listed banks in Ghana. Research Journal of Finance and Accounting, 3(4), 66-73.

Andre's et al. (2012). Board determinants in banking industry: an international perspective. Managerial Decision Economics, 33, 147158.

Andres, P. and Vallelado, E., (2008). Corporate governance in banking: the role of the board of directors. Journal of Banking \& Finance, $32,2570-2580$.

Ayuba, A. (2012) A proposed rule - roadmap for the adoption of international financial reporting standards (IFRS) in Nigeria: a research 
based perspective on FGN, NASB \& SEC. American Journal of Economics, Special Issue: 41-45 DOI: 10.5923/j.economics.20120001.10.

Bader, A. A. (2005). Compliance with international accounting standards by listed companies in the gulf co-operation council member states (Doctoral Thesis, University of Western Australia).

Bala, M. (2013). Effects of IFRS adoption on the financial reports of Nigerian listed entities: the case of oil and gas companies. The Macro theme Review, 2(7), 9-26.

Bank for International Settlement (BIS, 2014). Basel principles. available at www.bis.org.

Barako, D., Hancock, P. and Izan, H.Y. (2006). Relationship between corporate governance attributes and voluntary disclosures in annual reports: the Kenyan experience. Financial Reporting, Regulation and Governance, 5(1), 1-25.

Chalmers, K. (2001). The progression from voluntary to mandatory derivative instrument disclosures - Look who's talking. Australian Accounting Review, 11(1), 34-44.

Choi, F. D. S., Forst, C. A. \& Meek, G. K. (2002). International Accounting. 4th ed. New Jersey: Prentice-Hall.

Damant, D. (2002). A revolution in financial reporting. Balance Sheet, 10 (1), 4-7.

Daske, H., Hail, C. and Verdi, R. (2007) Adopting a Label: Heterogeneity in the Economic Consequences of IFRS Adoption. Initiative on Global Market, the University of Chicago Graduate School of Business.

Denning, S. (2013). Big banks and derivatives: why another financial crisis is inevitable.www.forbes.com/sites.

Edogbanya, A. \& Kamardin, H. (2014). Adoption of international financial reporting standards in Nigeria: concepts and issues. Journal of Advanced Management Science, 2(1), 72-75.

Glaum, M., \& Street, D. L. (2003). Compliance with disclosure requirement of Germany's new market: IAS versus GAAP. Journal of International Financial Management and Accounting, 14(1): 64-1000.

Hodgdon, C., Tondkar, R. H., Adhikari, A. \& Harless, D. W. (2009). Compliance with international financial reporting standards and auditor choice: new evidence on the importance of the statutory audit. The International Journal of Accounting, 44, 33- 55.

Hossain, Md. I. (2014). Regulatory Compliance of IFRS 7 of the Banks' Disclosures: A case study on of the Nationalized Commercial Banks of Bangladesh. Banglavision, 13(1), 115-123.

IASC (1996). International Accounting Standards 1996 - The full text of all International Accounting Standards extant at 1 January 1996 and current Exposure Drafts. London: IASC. IASC. (1997). Financial Instruments. IASC Update, (November 4).

International Monetary Fund (IMF, 2013). Nigeria: publication of financial sector assessment program documentation-detailed assessment of implementation of IOSCO objectives and principles of securities program. IMF country reports no 13/144.

Kemp, S. (2004). Bank hit by $\$ 180 m$ scandal. The Age, 14 January, 6.

Kirk, R.J. (2005). International financial reporting standards in depth. Elsevier Linacre house. Jordan Hill, Oxford.

Mainoma, M.A. and Adejola, A. P. (2010). Financial reporting standards- a comparative synthesis (new edition), Kaduna: Joyce Graphic Printers \& Publishers.

Marston, C. \& Shrives, P. (1991). The use of disclosure indices in accounting research: a review article. The British Accounting Review, 23(3), 195-210.

Nigerian Stock Exchange (NSE, 2012). Nigerian stock exchange 2012/13 fact book www.nse.com.ng

PricewaterhouseCoopers (PwC, 2013). International Financial Reporting Standards (IFRS) disclosure checklist. Inform.pwc.com. retrieved 12/12/2013.

Spector, S (2009) International Financial Reporting Standard 7 (IFRS 7), Financial Instruments: Disclosure, CGA-Canada, British Columbia, Canada.

Street, D. L., \& Bryant, S. M. (2000). Disclosure level and compliance with IASs: A comparison of compliance with and without U.S. listings and fillings. International Journal of Accounting, 35(3): 305-329.

Street, D. L., \& Gray, S. J. (2001). Observance of international accounting: factors explaining Non-compliance by companies referring to the use of IAS. London: ACCA Research Monograph No. 74.

Tan, C. W. (2005). Accounting for financial instrument: an investigation of preparer and user Preference for fair value accounting. PhD thesis, Murdoch University Perth, Western Australia. 
